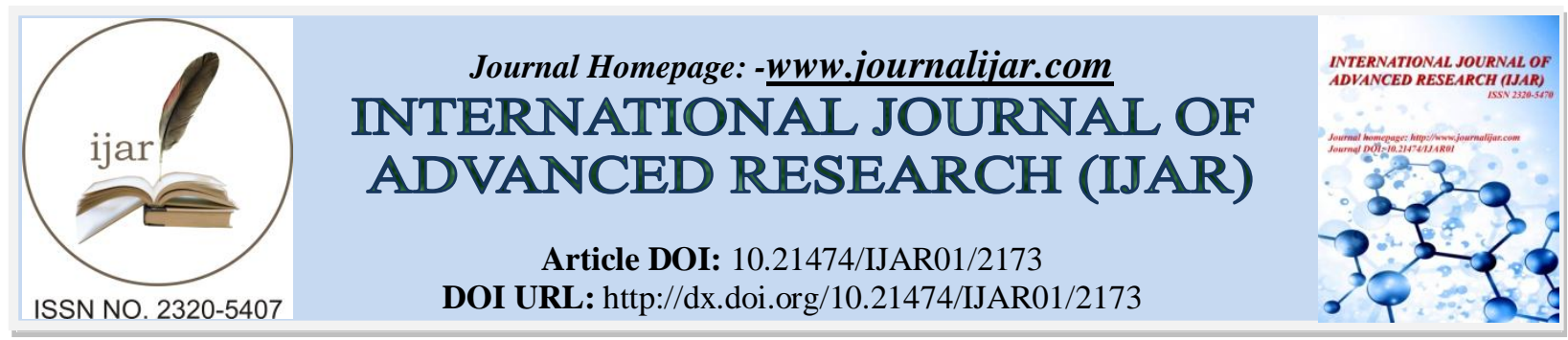

RESEARCH ARTICLE

\title{
EVALUATING THE MATTRU JONG WATER SUPPLY SYSTEM IN SIERRA LEONE.
}

*Ewusi A., Seidu J., Ahenkorah I., Eshemele N.K., Asante-Annor A. and Oti D.

Department of Geological Engineering, University of Mines and Technology (UMaT), Tarkwa, Ghana.

\section{Manuscript Info}

Manuscript History

Received: 26 September 2016

Final Accepted: 29 October 2016

Published: November 2016

Key words:-

Mattru Jong, Water Supply System, Jong River, Water Quality.

\begin{abstract}
To ensure sustainability of the water supply system in Mattru Jong, Sierra Leone and ameliorate the outbreak of water-borne diseases, the water sources in MattruJong were investigated for quality, quantity and availability. Water quality analyses were carried out on samples from the Jong River and boreholes in the area to ascertain their physicochemical and biological constituents. High presence of total iron and turbidity were found in the samples obtained from the Jong River. The water sources were all acidic with the exception of borehole sample $\mathrm{BH}_{2}$. Piper plots revealed $\mathrm{Na}^{+}-\mathrm{K}^{+}-\mathrm{Cl}^{-}-\mathrm{SO}_{4}{ }^{2-}, \mathrm{Ca}^{2+}-\mathrm{Mg}^{2+}-\mathrm{HCO}_{3}{ }^{-}$water types with intermediate chemical characteristics with no cation-anion pairs exceeding $50 \%$ as the hydrochemicalfacies of water in Mattru Jong. Bacteriological analyses indicated the presence of faecal coliforms in the surface water samples $\left(\mathrm{JON}_{1}, \mathrm{JON}_{2}, \mathrm{JON}_{3}\right)$. Results also show that the Jong River and boreholes $\left(\mathrm{BH}_{1}, \mathrm{BH}_{2}\right.$ and $\left.\mathrm{BH}_{3}\right)$ were sustainable sources for the water supply system.
\end{abstract}

Copy Right, IJAR, 2016,. All rights reserved.

\section{Introduction:-}

Most public water supply systems including the Mattru Jong water supply system located in Mattru Jong in the Bonthe District were destroyed in the course of the Sierra Leonean war which lasted between 1991 and 2001. The water supply system which depended solely on surface water to feed the system for treatment and supply was constructed with the degremont technology which included special dosing, clarification, aeration, flocculation and separation chambers. Essential components of the system were damaged during the war and this rendered the system ineffective and unable to meet the water demand of the inhabitants of Mattru Jong and other communities in the Bonthe District of Sierra Leone. Demand for potable water has increased after the war because most of the refugees have returned home resulting in an increase in the population. Because of this shortage in supply from the water supply system most of the inhabitants resort to the use of untreated surface water bodies and some unprotected hand dug wells for their daily water use. The Sewa creek (surface water) which is the source for the Mattru Jong water supply system before and after the war is not sustainable throughout the year making it impossible to extract suitable quantities of water needed for treatment and subsequent supply all year. Also the chemical and physical constituents of the water source are gradually deteriorating due to numerous anthropogenic activities carried out in the source area. It has therefore become necessary to find additional sources of potable water to feed the water supply system in Mattru Jong. The objectives of the study are to locate appropriate and potable water sources for the water supply system, determine the water quality and to recommend appropriate treatment options.

Corresponding Author:- Ewusi A.

Address:- Department of Geological Engineering, University of Mines and Technology (UMaT),

Tarkwa, Ghana. 
Mattru Jong is located in the Bonthe District in the southern part of Sierra Leone. The greater number of the inhabitants in this District and apparently Mattru Jong are of the Mende and Sherbor origin. Fig. 1 shows the thirteen (13) Districts and location of Mattru Jong in Sierra Leone. It is located along the Jong River and is about fifty-two miles (52 miles) southwest of Bo. The land is generally undulating with ranges of mountains and hills creating gorges and valleys giving it a very remarkable landscape (Levert, 2006). The country has a growth rate of $2.277 \%$ (Anon., 2012). Refugees currently in neighbouring countries are gradually coming home resulting in increase in the population. Currently the population of Mattru Jong is estimated at 10000.

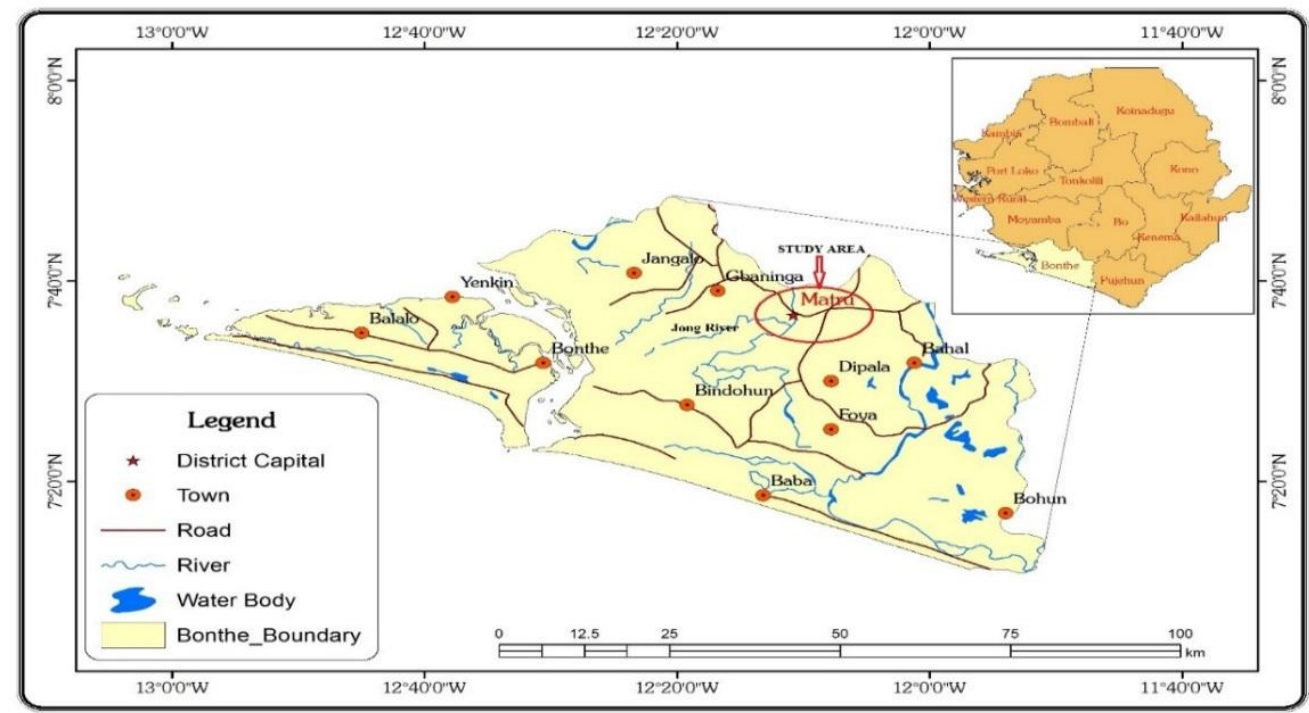

Fig. 2:- Map of Bonthe District showing the location of Mattru Jong

\section{Climate:-}

The climate of Mattru Jong can be classified as tropical monsoon though generally it is tropical. It is transitional between a continually wet tropical rain forest climate and a tropical savanna climate. The mean annual temperature is $26{ }^{\circ} \mathrm{C}$ ranging from a minimum of $22{ }^{\circ} \mathrm{C}$ in August to a maximum of $35^{\circ} \mathrm{C}$ in February. The dry season is from November to April and about (5-20) \% of the annual rainfall occurs during this season. The wet season occurs during months from May to October but practically ends in November. During this period the water bodies including streams, rivers and lakes acquire high volumes of water and total dissolved solids (TDS) are also high resulting in high turbidity to the surface water sources (Anon., 2007). The heaviest rains in Mattru Jong occur in July and August when the average number of rainy days is 27 (Johnson and Johnson, 1991). Evapotranspiration of $1300-$ $1600 \mathrm{~mm}$ annually is estimated for Mattru Jong, with daily rates varying between 3.5-4.5 mm. Air humidity could be as high as 80-90 \% according to monthly means during dry season and 70-80\% during the rest of the year (Anon, 1988).

\section{Geology and Hydrogeology:-}

Mattru Jong is located on the Bullom Series comprising an alternation of gravel, sand and clay.The tertiary sediments rest conformably on the Kasila Series and unconformably on the gabbro massif of the Western Area Peninsula (Fig. 2).The sequence consists of Eocene lignite-bearing clays with fauna of fish and molluscs overlain disconformably by quaternary gravels, sand and clays (Henley and Thornley, 1979). Concretions and nodules of clay ironstone and marcasite are common with the clay beds. The Bullom Series varies in thickness and there is the possibility that Late Cretaceous sediments are present beneath the Eocene sediments where the sequence is thick as is the case in the coastal strip of eastern Ivory Coast where similar sediments occur (Anon., 1988). The rocks have no primary porosity and groundwater accumulation therefore occurs in fractures. The aquifers are discontinuous. Mattru Jong has undergone series of tectonic activities which has resulted in the formation of secondary structures as fissures and solution channels which have facilitated the accumulation of groundwater(Morel, 2006). The fissures of the ground (5-10) $\mathrm{m}$ are interconnected and this has contributed to accumulation of surface water especially the bays and artificial lakes. Since the aquifersare shallow, a lot of hand dug wells have been constructed inMattru Jong with few boreholes confirming shallow aquifer systems. Hydrogeological mapping carried outduring fieldwork showed that hand dug well depths are between (4-10) $\mathrm{m}$. 


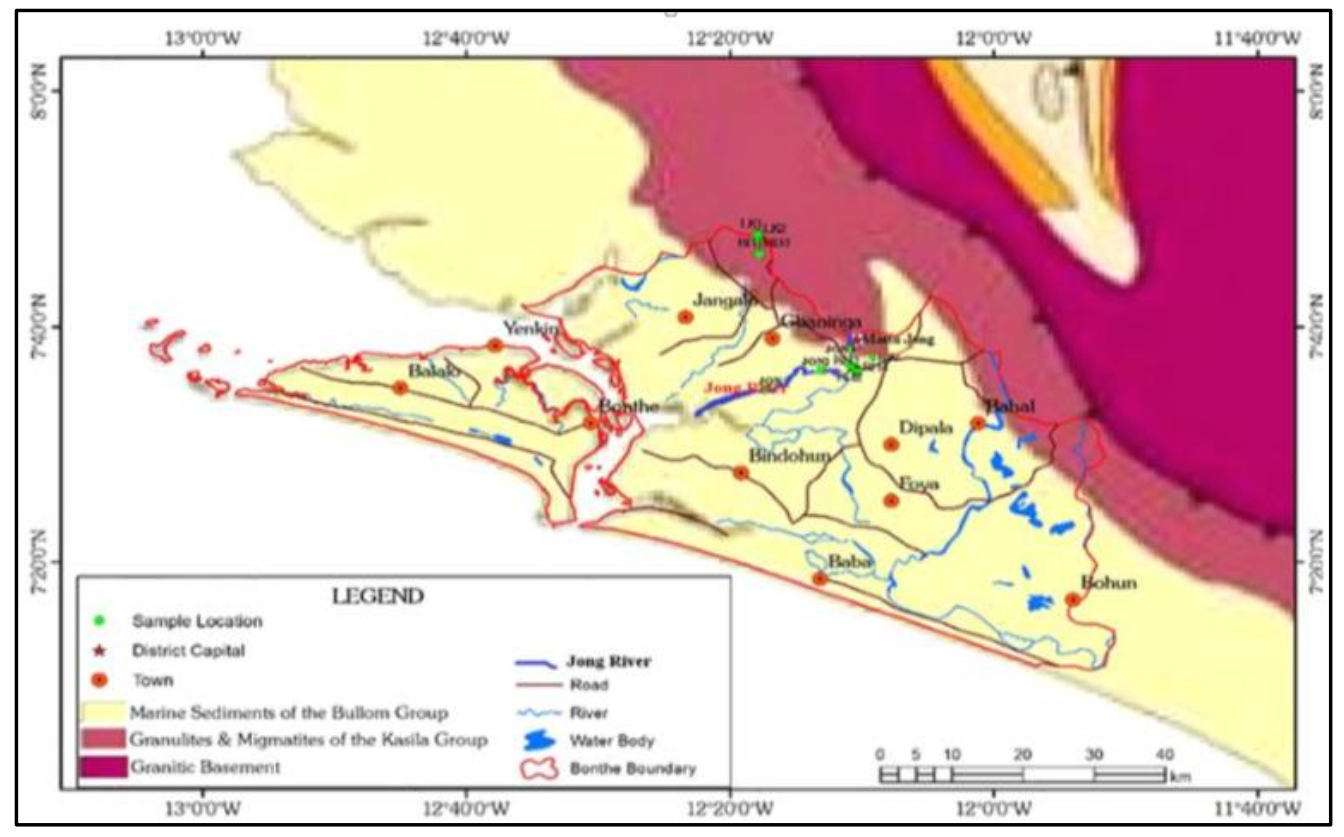

Fig. 2:- Geology map of Mattru Jong Area

\section{Water Resources:-}

The Bonthe District has the Jong River, Scarcies River, Sierra Leone River and the Yawri Bay. The Scarcies River is tidal and during the rainy season rises about $2.7 \mathrm{~m}$. The wide estuary mouth has mud banks and sand bars forming Yeliboya, Kortimaw, Yeligbungbo and Bankapia Islands. In the inland the Scaries River splits into the Great and Little Scarcies rivers which are relatively narrow (Anon., 2014). Within the Sierra Leone River hydrological area are the Rokel, Port Loko and Kumrabe creeks. There are also major river systems involving the Taia, Sewa and Wange Rivers. The three major river systems enter the Sherbro River estuary through a complex system of brackish water channels draining an extensive area behind the ancient beach ridges in the South east region. The water divides around Sherbro Island and flows west into Yawri Bay and south along Turner's Peninsula (Daveau, 1871). The Yawri Bay comprises of three small rivers;Ribbi, Kukuli and Kagboroko which rise inland and reach the bay. Several small creeks are also connected to the sea and river systems. The volume of inflow from their catchments and rivers are high during the rainy season resulting in high runoff from the catchments. During the wet season, the excess of precipitation which cannot be stored in the groundwater represent the amount of rainfall input that become available as run-off. The water balance show that there is a 'water surplus' $2000-2200 \mathrm{~mm}$, which is higher than 'water deficit' during the dry season (Anon., 1988).

\section{Materials and Methods:-}

Primary and secondary data were obtained from the field, various agencies and institutions in charge of water supply in Sierra Leone. Primary data included pumping test and flow rate estimation and water sample analysis results. Secondary data were obtained from Sierra Leone Water Company (SALWACO) who managed and monitored the Mattru Jong water supply system before its destruction.

\section{Climatological Studies:-}

The climatological data was used to characterise the climatic conditions of the area. Average monthly rainfall data recorded from the period 1960-2009 was compiled in Microsoft Excel. The average monthly rainfall data was ranked from the greatest to the least and assigned a serial rank, a, starting from 1 for the greatest value and $b$, the number of data values (Okun, 1994). Probability (P) as a percentage of time rainfall which will be equaled or exceeded as well as flow rates werecalculated using Equation 1.

$$
\mathrm{P}=100\left[\frac{\mathrm{a}}{\mathrm{b}+1}\right]
$$

A plot of $\mathrm{P}$ as a function of rainfall and flow rates yielded a duration curve showing the percentage of time a given rainfall or flow rate equaled or exceeded. 


\section{Estimation of the Flow Rate for River Jong:-}

The flow rate was estimated to determine the quantities of water that can be obtained from the river at a time to meet the demand of the inhabitants as well as to maintain the water balance.The flow rate $\left(\mathrm{m}^{3} / \mathrm{s}\right)$ of the Jong River was estimated using the float and cross section area method.The Jong River is very wide with no bridge constructed across it. There is no gauge to monitor the level of the Jong River periodically. For this reason, run-off data and the river flow information is not readily available. An estimate of the flow rate had to be established to be used for this work. A live boat was used on the river to determine the width of the river at different points on the course of the river to establish the average width. A portion of the width of river very close to the average width was selected. A cross section was established along that width. The depth of the river was recorded at constant intervals along the selected width of the river. A constant interval of $10 \mathrm{~m}$ was used instead of (1-2 m) because of the large width of the river and dangers involved in working on the river. The interval was multiplied by the depth to determine the area at that interval. Different distances $(2,3,5,7,10,15$ and 20) $\mathrm{m}$ were preliminary employed in estimating the velocity. The selected portion of the Jong River was straight (no bends) and free of obstacles and pool forming as indicated in the work of Murdoch and Cheo (1996). It was also realised that the longer the distance, the farther of float from the immediate view and as a result stop watch reading were not accurate. For this reason a distance of $3 \mathrm{~m}$ was used instead of $6.11 \mathrm{~m} \mathrm{(20} \mathrm{ft)} \mathrm{used} \mathrm{in} \mathrm{most} \mathrm{programmes} \mathrm{(Murdoch} \mathrm{and} \mathrm{Cheo,} \mathrm{1996).} \mathrm{The} \mathrm{process} \mathrm{was} \mathrm{repeated} \mathrm{to}$ establish the average velocity of the river. The friction correction factor was multiplied by the velocity since the surface and the bottom of the river are different in terms of regularity. A factor of 0.85 was considered because the bottom is assumed to be rough (Harrelson et al., 1994).

\section{Pumping Test Analysis:-}

Pumping test was conducted on three boreholes to establish the safe yield. Constant discharge was carried out for 16 hours using the airlift yield as a reference. The Cooper-Jacob Straight line software built in Microsoft Excel was used in the analysis of pumping test data because when non-equilibrium is achieved in the case of these pumping, the Cooper-Jacob is most preferred. The dynamic water levels recorded were input into the software with their corresponding time and discharge. Drawdowns were calculated by computation in the software by means of deducting the static water level from the dynamic water levels. To establish the residual drawdowns of the recovery, the differences at the dynamic water level where recovery started and the current recovery level were calculated and the result deducted from the level where recovery begun. The achieved result is the residual recovery. The process was repeated to achieve all the drawdowns for the test. A graph of drawdown against time was produced. In the case of the recovery graph, time ( $\left.t / t^{\circ}\right)$ and residual recovery were used to produce the graph. This method was applied because there was long hour constant discharge. The line of best fit which is a component of the software graph is dragged at the anchors within the region $(\mathrm{u}>0.05)$ to obtain a straight line intercepting the plotted points. Through this the gradient $(\Delta \mathrm{s})$ was achieved. By the application of equation 2, the transmissivity of the boreholes were obtained.

$$
T=\frac{0.185 Q}{\Delta s}
$$

Where:

$\mathrm{T}$ is the transmissivity, in $\mathrm{m}^{2} / \mathrm{s}$

$\mathrm{Q}$ is the constant discharge $\left(\mathrm{m}^{3} / \mathrm{s}\right)$ and $(\Delta \mathrm{s})$ is the gradient of the graph for one log cycle.

\section{Estimation of Water Demand:-}

The demand of water for the Mattru Jong water supply system was estimated using aper head of $0.063 \mathrm{~m}^{3} / \mathrm{d}$. The demand was estimated for a 10 year period using the projected population of the town. The exponential growth equation was also used in the population estimation for 10 years using the country's current growth rate of $2.277 \%$ as determined by equation 3 .

$\mathrm{P}=\mathrm{P}_{1}(1+\mathrm{r})^{\mathrm{n}}$

$\mathrm{P}=$ Estimated population

$\mathrm{P}_{1}=$ current population

$\mathrm{r}=$ growth rate

$\mathrm{n}=$ projected years. 


\section{Water Sampling and Analysis:-}

Water samples were taken from three points in the Jong River at the upstream, middle and downstream. Groundwater samples were also obtained from three boreholes $\left(\mathrm{BH}_{1}, \mathrm{BH}_{2}\right.$ and $\left.\mathrm{BH}_{3}\right)$. The samples were collected at a favourable time $(9.00 \mathrm{am})$ of the day when parameters were assumed to be stable. To avoid any unpredictable change in composition of the collected samples, the bottles used were acid washed according to the standards (Anon., 1999). The bottles were then immersed to about $0.3 \mathrm{~m}$ to allow the water to flow into it by natural force. Filtration of the collected samples was done with $0.45 \mu \mathrm{m}$ membrane. The sample bottles were filled to the brim to exempt oxygen and it was labelled and stored in an ice chest. The water samples were analysed in the laboratory following the procedures documented in the standard methods for the examination of water and waste water (Anon., 1999). The Water quality data were analysed using the Hydrochemical Analysis Model (HAM) software which is built in Microsoft Excel.

\section{Results and Discussions:-}

Rainfall and Flow Rate Analysis:-

A graph of the rainfall amount (mm) against months was plotted (Fig. 3). The run-off data for the Jong River was not available and had to be estimated. The Jong River is $245 \mathrm{~km}$ long and its basin covers approximately $7500 \mathrm{~km}^{2}$. The nominal equation is applicable only when the basin covers a maximum of 200 acres (100 hectares) (Kuma, 2010). The estimated flow rate of the Jong River conducted in March was used to deduce the flows for the other months based on the assumption that average monthly rainfall or precipitation will be proportional to average monthly flows when influencing factors like infiltration, storage, evapotranspiration, evaporation and discharge from groundwater in all seasons remain the same within the Mattru Jong area. Ideally, these factors are different in wet and dry seasons. They are low in wet season and high in the dry season so using the dry season flows to project for the rainy season gives feasible assumptions for the river.The flow rate estimation was carried out in the month of March because it is the month that ends the dry season and in the absence of storage, safe yield of the Jong River can be deduced as the lowest weather flow in the dry season (Okun, 1994). By simple proportion the flow rates for the other months were estimated. The applied method is only an assumption to deduce an estimate of the flows to determine assumed exceedance probability since flows and run-off data are not available. Probability duration curve was plotted to estimate a given time flow rate will be equaled or exceeded. The exceedance probability was considered at $50 \%, 80 \%$ and $95 \%$. However $95 \%$ was used for the estimation and calculations to be able to ascertain the right volume of water in the basin at most times ( $95 \%$ of the time).The flow rate was $450 \mathrm{~m}^{3} / \mathrm{s}$ for 50 $\%, 80 \mathrm{~m}^{3} / \mathrm{s}$ for $80 \%$ and $17 \mathrm{~m}^{3} / \mathrm{s}$ for $95 \%$ exceedance probabilities (Fig. 4). Records show that for the past 49 years $17 \mathrm{~m}^{3} / \mathrm{s}$ of water at most times has been the sustainable quantity of water in the channel of the Jong River.

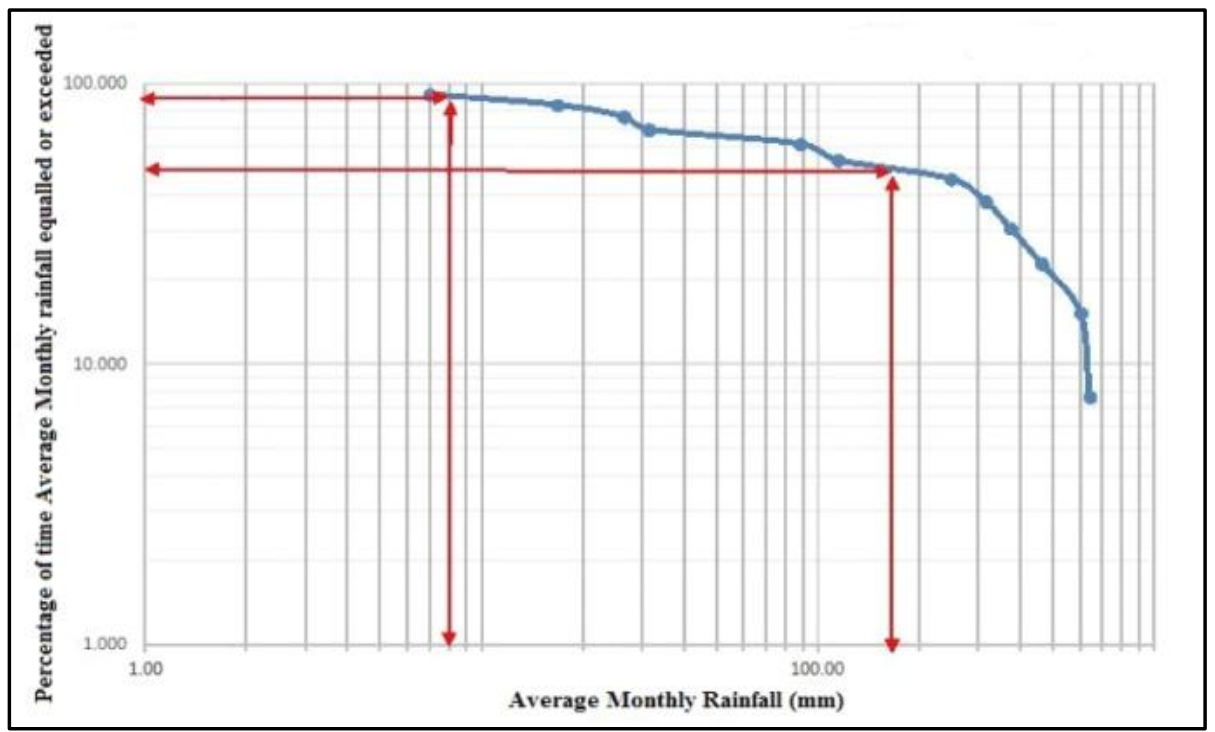

Fig. 3:- Duration curve of Average Monthly Rainfall in Mattru Jong (1960-2009) 


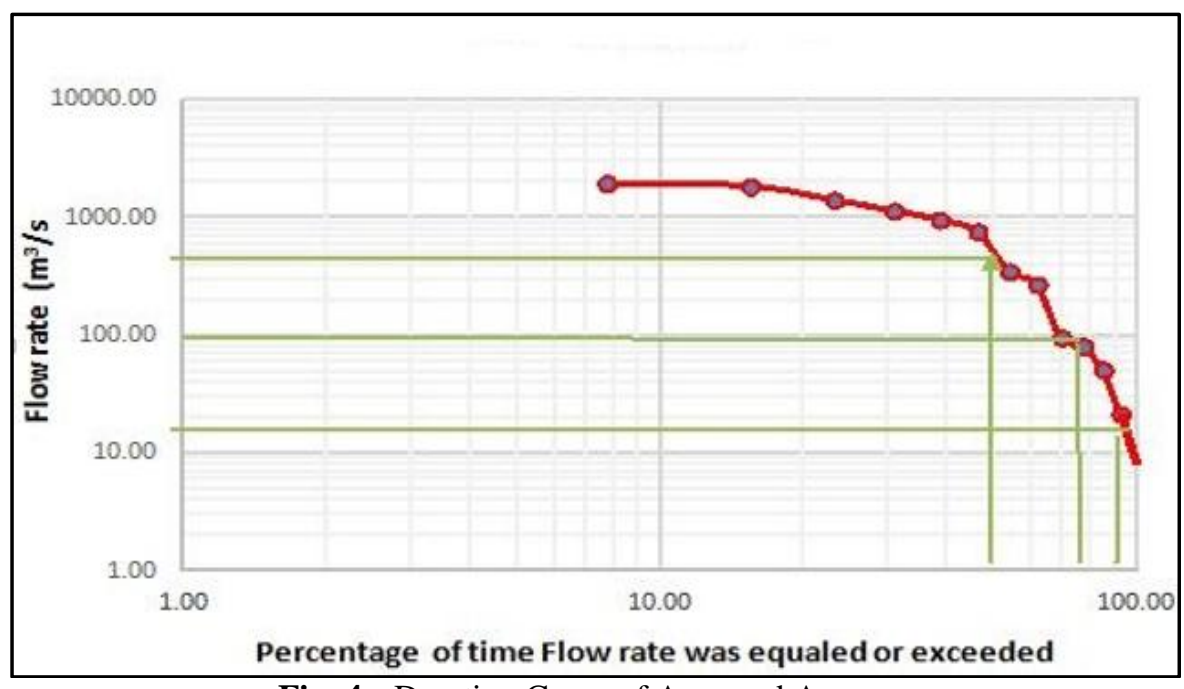

Fig. 4:- Duration Curve of Assumed Average

The average velocity obtained was $0.27 \mathrm{~m} / \mathrm{s}$. This was corrected by the friction factor of 0.85 (Harrelsonet al., 1994) to establish the velocity of the river by the application of equation 4.

$\mathrm{V}=\mathrm{AVr} \times \mathrm{Ff}$

Where $\mathrm{V}$ is the velocity of the Jong River and Ff is the friction factor (0.85)

The velocity of the Jong River was estimated at $0.23 \mathrm{~m} / \mathrm{s}$ with a cross sectional area of $422.82 \mathrm{~m}^{2}$ given an estimated flow rate $\mathrm{Q}$ of $96.83 \mathrm{~m}^{3} / \mathrm{s}$.

\section{Pumping Test Results:-}

The aquifer in the area is very productive. $\mathrm{BH}_{1}$ had a yield of $288 \mathrm{~m}^{3} / \mathrm{d}$ with average transmissivityof $4.515 \mathrm{~m}^{2} / \mathrm{d}$ and maximum drawdown of $21.63 \mathrm{~m}$. A yield of $345 \mathrm{~m}^{3} / \mathrm{d}$ was obtained from $\mathrm{BH}_{2}$ with average transmissivity of 3.17 $\mathrm{m}^{2} / \mathrm{d}$ and $20.25 \mathrm{~m}$ maximum drawdown. $\mathrm{BH}_{3}$ had a yield of $144 \mathrm{~m}^{3} / \mathrm{d}$ with average transmissivity was $1.91 \mathrm{~m}^{2} / \mathrm{d}$ and maximum drawdown of $21.9 \mathrm{~m}$. The transmissivity of the boreholes $\left(\mathrm{BH}_{1}, \mathrm{BH}_{2}\right.$ and $\left.\mathrm{BH}_{3}\right)$ shows that the water in the aquifer is sustainable.

\section{Demand for the Water Supply System:-}

Since the water supply will also supply water to other parts of the Bonthe District and not only Mattru Jong, the population of the Bonthe District was considered. Currently the population in Bonthe District is estimated at 16000 incudingMattru Jong. The projected population for the 10 years period will be 20040 and water demand of 1,202.40 $\mathrm{m}^{3} / \mathrm{d}$ is expected. Population growth projections were estimated using a $2.277 \%$. Water demand calculations were made with the assumption that an individual uses $0.063 \mathrm{~m}^{3} / \mathrm{d}$. The current demand of water for Mattru Jong and the Bonthe District are $587 \mathrm{~m}^{3} / \mathrm{d}$ and $960 \mathrm{~m}^{3} / \mathrm{d}$ respectively. Table 1 elaborates the population estimates with corresponding water demand.

Table 1:-Estimate of Water demand (/d)

\begin{tabular}{|c|c|c|c|c|}
\hline \multirow{2}{*}{ Location } & \multicolumn{2}{|c|}{ Population } & \multicolumn{2}{|c|}{ Average Water Demand $\left(\mathrm{m}^{3} / \mathrm{d}\right)$} \\
\hline & Current (2015) & Estimated (2015) & Current (2015) & Estimated (2015) \\
\hline Bonthe District & 16000 & 20040 & 960 & 1202.40 \\
\hline Mattru Town & 10000 & 10269 & 538.26 & 616.14 \\
\hline
\end{tabular}

\section{Estimation of Available Volumes of Water:-}

The percentage estimate of available water from the Jong River and the boreholes are summarised in table 2. Using $95 \%$ exceedance probability of the Jong River, $17 \mathrm{~m}^{3} / \mathrm{s}$ is available $95 \%$ of the time. This is equivalent to $1.4688 \mathrm{x}$ $10^{6} \mathrm{~m}^{3} /$ d. (10-70) \% of this available water in the Jong can be redrawn for use. In this estimate, $10 \%$ and $70 \%$ of the available volumes of water are $0.14688 \times 10^{6} \mathrm{~m}^{3} / \mathrm{d}$ and $1.02816 \times 10^{6} \mathrm{~m}^{3} / \mathrm{d}$ respectively which are higher than the current and projected water demand of the Mattru Jong town and the Bonthe District. Available surface water in the 
Jong can meet the demand for the water supply scheme. However because less treatment cost is required using groundwater and also to safeguard the possibility of the Jong river drying up, the boreholes were also considered. The boreholes $\left(\mathrm{BH}_{1}, \mathrm{BH}_{2}\right.$ and $\left.\mathrm{BH}_{3}\right)$ yielded a volume of $777 \mathrm{~m}^{3} / \mathrm{d}$. The possible volume of abstraction shows that the conjunctive use of surface and groundwater can meet the demand of Mattru Jong and the entire Bonthe District for the present (2015) and future (2025) in terms of quantity.

Table 2:-Possible Volumes of water Available for Redrawal in Mattru Jong

\begin{tabular}{|l|c|c|}
\hline \multicolumn{3}{|c|}{ Available Surface Water from Jong River } \\
\hline Exceedence Probability & \% Abstraction $\left(\mathbf{m}^{3} /\right.$ day) $\mathbf{X ~ 1 0}$ & Flow Rate $\left(\mathbf{m}^{\mathbf{3}} / \mathbf{s}\right)$ at 95\% (EP) \\
\hline $95 \%$ & 1.4688 & 17 \\
\hline \multicolumn{3}{|c|}{ Proposed redrawal fromavailable water in Jong River } \\
\hline Percentage & \% Abstraction $\left(\mathbf{m}^{3} /\right.$ day) X 10 & \\
\hline $70 \%$ of water Available & 1.02816 & \\
\hline $50 \%$ of water Available & 0.7344 & \\
\hline $20 \%$ of water Available & 0.29376 & \\
\hline $10 \%$ of water Available & 0.14688 & \\
\hline Boreholes & Abstraction $\left(\mathbf{m}^{3} / \mathbf{d a y}\right)$ & \\
\hline $\mathrm{BH}_{1}$ & 288 & \\
\hline $\mathrm{BH}_{2}$ & 345 & \\
\hline $\mathrm{BH}_{3}$ & 144 & \\
\hline Total Yield & $\mathbf{7 7 7}$ & \\
\hline
\end{tabular}

\section{Water Quality Analyses:-}

In water supply for human consumption it is always a requisite to know the sustainability and availability of the source of the water supply, its hydrochemical and hydrogeochemical constituents to understand the history of the environment in which the water has circulated. The hydrochemical constituents of the water sources (surface and groundwater) were analysed to understand the general hydrochemistry and hydrogeochemistry of the area. All analysed water quality parameters were compared with the standard WHO guideline for the water to be accepted for human consumption. In the case where the values of the physico-chemical parameters are above the WHO guideline the water can be used for other purposes but not for human consumption otherwise it must be treated effectively before consumption. Table 3 shows the results of the analysis of the water samples.

Turbidity of both the surface and groundwater samples were between 2 to 16 NTU with an average of 6.2 NTU.Turdity was high for the surface water sources $\left(\mathrm{JON}_{1}, \mathrm{JON}_{2}, \mathrm{JON}_{3}\right)$. This could be as a result of surface run-off of sediments and dissolved solids into the water sources and mining activities which dispose most waste products into nearby streams and rivers. Consumption of high turbid water poses health hazards to consumers and high turbidity may also create a shield of protection for micro bacteria when disinfection is done (Gadgil, 1998).Also the colour of water sources in the study area and turbidity are related.High colour corresponds to high turbidity. The colour of the water sources are within the range of the WHO guideline (table 3). The surface water sources have higher values of colour in general and confirm the direct contact and exposure of the surface water sources to seepage, precipitation and run-off. Higher colour makes water unpleasant for consumption.

Results depicted a low $\mathrm{pH}$ ranging from 4.5 to 7.7 with an average of 6.07 . With the exception of $\mathrm{BH}_{1}$ and $\mathrm{BH}_{2}$, the $\mathrm{pH}$ of the other water sources were generally low. The low $\mathrm{pH}$ may be due to the presence of silica acid (Kesse, 1985). Wright (1982) assigned low pH of the Jong River to acid rain and acidic ephemeral stream that flows into the Jong River. The low pH may lead to dissolution of heavy metals in the rocks into the water sources. However no record of heavy metals has been measured yet in groundwater sources in the study area.

The results of the TDS were within a range of $12 \mathrm{mg} / \mathrm{L}$ to $125 \mathrm{mg} / \mathrm{L}$ and a mean of $40.07 \mathrm{mg} / \mathrm{L}$. The results however were below the WHO guideline value of $1000 \mathrm{mg} / \mathrm{L}$. Comparing the groundwater and surface water, it is evident that the surface water recorded lower TDS values. The groundwater sources have higher TDS values due to the acidic nature of the groundwater which allows the dissolution of highly soluble rocks or substances in the rock components or infiltrated water. The acidity of the groundwater sources may also account for the reason why the groundwater has relatively high electrical conductivity (EC) than the surface water. The EC values had an average 
value of $155.3 \mu \mathrm{S} / \mathrm{cm}$ within a range of $21.9 \mu \mathrm{S} / \mathrm{cm}$ and $477 \mu \mathrm{S} / \mathrm{cm}$. Total suspendedsolids (TSS) recorded an average of $2.78 \mathrm{mg} / \mathrm{L}$ with a minimum and maximum values of $0.8 \mathrm{mg} / \mathrm{L}$ and $6 \mathrm{mg} / \mathrm{L}$ respectively.

Table 3:-Water Quality Analysis Results of Water Samples

\begin{tabular}{|c|c|c|c|c|c|c|c|c|}
\hline \multirow{2}{*}{ Parameter } & \multirow{2}{*}{ Unit } & \multirow{2}{*}{ WHO Limit } & \multicolumn{3}{|c|}{ Groundwater } & \multicolumn{3}{|c|}{ Surface water } \\
\hline & & & $\mathbf{B H}_{1}$ & $\mathbf{B H}_{2}$ & $\mathbf{B H}_{3}$ & $\mathrm{JON}_{1}$ & $\mathrm{JON}_{2}$ & $\mathrm{JON}_{3}$ \\
\hline Turbidity & NTU & 5 & 3 & 5 & 3 & 6 & 7 & 15 \\
\hline Colour & $\mathrm{Hz}$ & 15 & 5 & 10 & 1 & 10 & 10 & 10 \\
\hline pH & & $6.5-8.5$ & 7.70 & 7.66 & 5.86 & 6.23 & 5.87 & 5.94 \\
\hline Conductivity & $\mu \mathrm{S} / \mathrm{cm}$ & - & 155 & 227 & 477 & 21.9 & 25.6 & 25.1 \\
\hline TSS & $\mathrm{mg} / \mathrm{L}$ & - & 2 & 4 & 0.8 & 3 & 0.88 & 6 \\
\hline TDS & $\mathrm{mg} / \mathrm{L}$ & 1000 & 85.3 & 125 & 26.2 & 12 & 14.1 & 13.8 \\
\hline $\mathrm{Na}^{+}$ & $\mathrm{mg} / \mathrm{L}$ & 200 & 16 & 5 & 24 & 2 & 1.8 & 1.9 \\
\hline $\mathbf{K}^{+}$ & $\mathrm{mg} / \mathrm{L}$ & 30 & 2.82 & 1.74 & 1.82 & 0.60 & 0.40 & 0.40 \\
\hline $\mathrm{Ca}^{2+}$ & $\mathrm{mg} / \mathrm{L}$ & 200 & 3.82 & 16.30 & 2.30 & 0.80 & 1.60 & 0.40 \\
\hline $\mathrm{Mg}^{2+}$ & $\mathrm{mg} / \mathrm{L}$ & 150 & 0.40 & 7.40 & 1.00 & 0.60 & 0.50 & 0.70 \\
\hline Total Iron & $\mathrm{mg} / \mathrm{L}$ & 0.3 & 0.01 & 0.083 & 0.084 & 0.95 & 1.32 & 0.85 \\
\hline $\mathrm{Cl}^{-}$ & $\mathrm{mg} / \mathrm{L}$ & 250 & 13.9 & 2 & 2 & 2 & 2 & 2 \\
\hline $\mathrm{SO}_{4}$ & $\mathrm{mg} / \mathrm{L}$ & 250 & 29.20 & 4.79 & 2.45 & 2.13 & 2.00 & 0.90 \\
\hline $\mathrm{PO}_{4}-\mathrm{P}$ & $\mathrm{mg} / \mathrm{L}$ & - & 0.166 & 0.153 & 0.241 & 0.189 & 0.505 & 0.553 \\
\hline $\mathrm{HCO}_{3}^{-}$ & $\mathrm{mg} / \mathrm{L}$ & - & 3.9 & 96.9 & 17.6 & 4.9 & 6.8 & 6.8 \\
\hline $\mathrm{NO}_{3}-\mathrm{N}$ & $\mathrm{mg} / \mathrm{L}$ & 10 & 0.47 & 0.139 & 0.283 & 0.216 & 0.162 & 0.16 \\
\hline TH & $\mathrm{mg} / \mathrm{L}$ & 500 & 11.2 & 71 & 10 & 4.6 & 6 & 4 \\
\hline TA & $\mathrm{mg} / \mathrm{L}$ & - & 9.4 & 40.7 & 5.8 & 2 & 410 & 1 \\
\hline
\end{tabular}

"TA=Total Alkalinity; TH=Total Hardness

Calcium concentration was within the accepted WHO guidelines of $200 \mathrm{mg} / \mathrm{L}$. Calcium was within a range of 0.4 $\mathrm{mg} / \mathrm{L}$ to $16.3 \mathrm{mg} / \mathrm{L}$ and an average of $4.2 \mathrm{mg} / \mathrm{L}$. Groundwater sample results showed a high concentration of calcium compared to the surface water samples. Calcium content in adequate and right proportions in water promotes strong bones and teeth, helps in blood clotting and enhances metabolic reactions (Anon., 2004). Total iron in the surface water samples were high compared to the groundwater. This may be as result of the presence of minerals like pyrite, hematite and siderite (Sengupa, 1992) in the basin or around the surroundings of the river bed. Acid rain may dissolve these minerals and flow into the river as run-off. In general, the iron values were within the accepted value of $0.3 \mathrm{mg} / \mathrm{L}$.

Magnesium, sodium and potassium values were acceptable within the WHO standard guideline values of $150 \mathrm{mg} / \mathrm{L}$, $200 \mathrm{mg} / \mathrm{L}$ and $30 \mathrm{mg} / \mathrm{L}$ respectively. The results of the other constituents also showed that chloride, sulphates, total hardness, magnesium hardness, total alkalinity, calcium hardness, fluoride, bicarbonate, nitrite, nitrate were all within the accepted range of the WHO drinking water guidelines. Phosphate was within $0.153 \mathrm{mg} / \mathrm{L}$ to $0.55 \mathrm{mg} / \mathrm{L}$. Coliform test conducted in the field and laboratory showed the presence of faecal coliforms in the surface water samples $\left(\mathrm{JON}_{1}, \mathrm{JON}_{2}, \mathrm{JON}_{3}\right)$.

\section{Water Type in the Study Area:-}

The Piper plot was used to plot the hydrochemical results from the water samples (Fig. 5). Plots were done for both surface and groundwater sources. The results are summarised in table $4 . \mathrm{BH}_{1}$ was deduced to be saline and noncarbonate alkalis exceed $50 \%$. It is high of $\mathrm{Na}^{+}-\mathrm{K}^{+}-\mathrm{Cl}^{-}-\mathrm{SO}_{4}{ }^{2-}$ water type. It could be possibly due to brine and sea water. $\mathrm{BH}_{3}$ exhibited similar characteristics of no cation-anion pairs exceeding $50 \%$ and can be deduced that the water is of an intermediate chemical character. $\mathrm{BH}_{2}$ showed temporary hardness and carbonate hardness exceeding $50 \%$. It showed a fingerprint of $\left(\mathrm{Ca}^{2+}-\mathrm{Mg}^{2+}-\mathrm{HCO}^{3-}\right)$ water type. It is fresh water and the possible host rock is dolerite. $\mathrm{JON}_{1}$ can be described as $\left(\mathrm{Na}^{+}-\mathrm{K}^{+}-\mathrm{Cl}^{-}-\mathrm{SO}_{4}{ }^{2-}\right)$ water type. Their chemical constituents may be as a result of the closeness to the sea, brine or saline water. $\mathrm{JON}_{1}$ may confluence the sea water at this area. $\mathrm{JON}_{2}$ and $\mathrm{JON}_{3}$ indicated a chemical characteristic and a fingerprint of $\left(\mathrm{Ca}^{2+}-\mathrm{Mg}^{2+}-\mathrm{HCO}^{3-}\right)$ water type. $\mathrm{JON}_{2}$ and $\mathrm{JON}_{3}$ were sampled at the upstream part of the Jong River and their chemical constituents confirm the fact that downstream is saline because of confluence with the sea. 


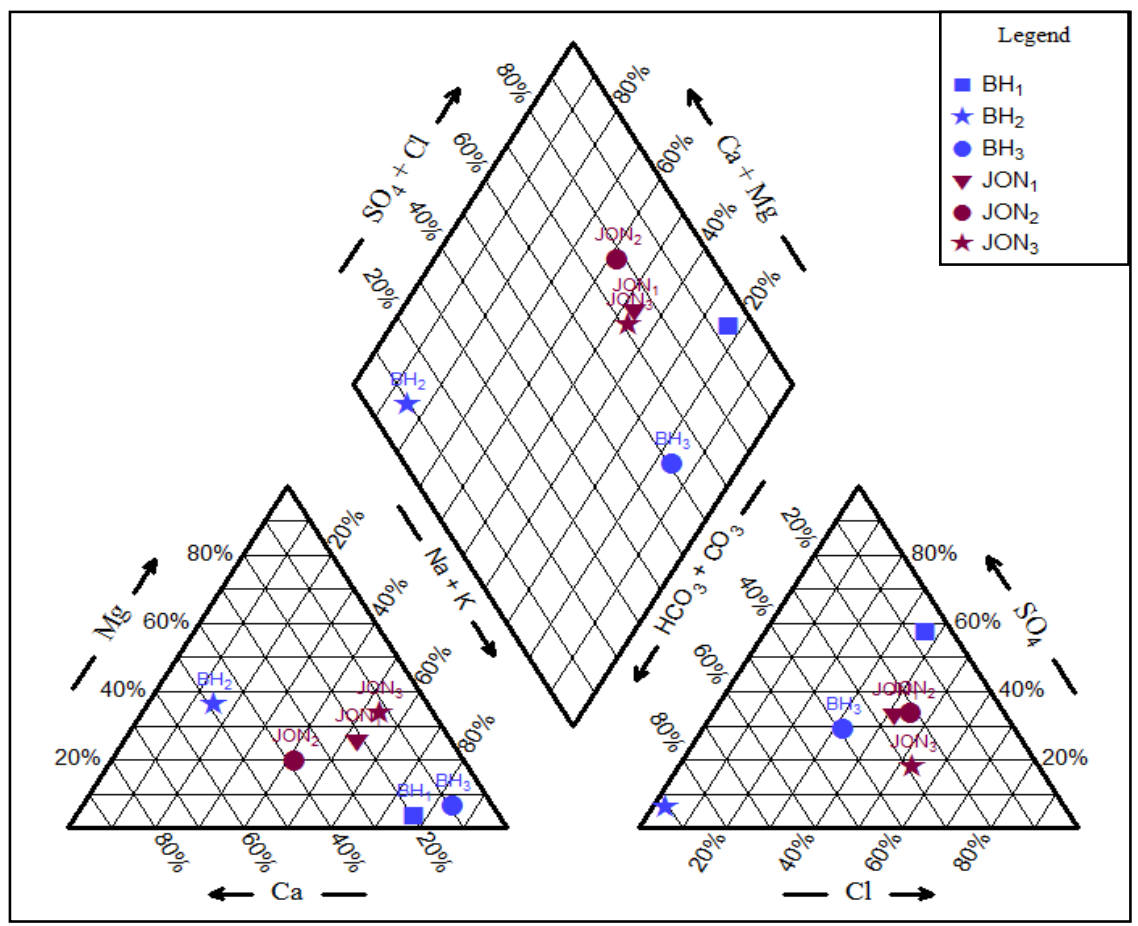

Fig. 5:- Piper Plot of Water Samples

Table 4:-Water Type of the Sampled Water

\begin{tabular}{|c|c|}
\hline \multicolumn{2}{|c|}{ Water Sources } \\
\hline Groundwater & Water Type \\
\hline $\mathrm{BH}_{1}$ & $\mathrm{Na}^{+}-\mathrm{K}^{+}-\mathrm{Cl}^{-}-\mathrm{SO}_{4}{ }^{2-}$ \\
\hline $\mathrm{BH}_{2}$ & $\mathrm{Ca}^{2+}-\mathrm{Mg}^{2+}-\mathrm{HCO}_{3}{ }^{-}$ \\
\hline $\mathrm{BH}_{3}$ Intermediate Chemical Character \\
\hline Surface Water & Water Type \\
\hline $\mathrm{JON}_{1}$ & $\mathrm{Na}^{+}-\mathrm{K}^{+}-\mathrm{Cl}^{-}-\mathrm{SO}_{4}{ }^{2-}$ \\
\hline $\mathrm{JON}_{2}$ & $\mathrm{Ca}^{2+}-\mathrm{Mg}^{2+}-\mathrm{HCO}^{3-}$ \\
\hline $\mathrm{JON}_{3}$ & $\mathrm{Ca}^{2+}-\mathrm{Mg}^{2+}-\mathrm{HCO}^{3-}$ \\
\hline
\end{tabular}

\section{Conclusions and Recommendations:-}

\section{Conclusions:-}

Results showed that a conjunctive use of water from the Jong River and groundwater sources from $\mathrm{BH}_{1}, \mathrm{BH}_{2}$ and $\mathrm{BH}_{3}$ can meet the demand of Mattru Jong town system. The Mattru Jong water supply can also supply sustainable water to the entire Bonthe District.The water sources however must be treated effectively because total iron concentration were high in the Jong River $\left(\mathrm{JON}_{1}, \mathrm{JON}_{2}\right.$ and $\left.\mathrm{JON}_{3}\right)$. The topsoil in the area is compacted laterite, magnetite and haematite which are iron bearing minerals. High precipitation or heavy rains have caused the eroding, weathering and possible dissolution of some of these minerals into the Jong River through surface runoff. The mining of economic iron and rutile may also have contributed to the high presence of iron in the Jong River through improper discharge of waste into streams and rivers by the mining activities. The groundwater sources were identified to be quiet saline, temporal hardness and of intermediate characteristics respectively however they could be treated to support the water supply system. The water sources are soft in terms of water hardness and can be used for domestic and industrial laundry purposes. It can also be concluded based on the sample locations that the water types in the granulites and migmatites of the Kasila Group are of intermediate chemical character and $\left(\mathrm{Na}^{+}-\mathrm{K}^{+}-\mathrm{Cl}\right.$ $\left.\mathrm{SO}_{4}{ }^{2-}\right)$. The Marine sediments of Bullom Group however has $\left(\mathrm{Ca}^{2+}-\mathrm{Mg}^{2+}-\mathrm{HCO}^{3-}\right)$ which is of temporal hardness and exhibit intermediate chemical characteristics. 


\section{Recommendations:-}

It is recommended that continuous sand filtration and potassium permanganate greensand filtration system in conjunction with Sotrad should be used to treat the water from the Jong River. The catchment regions should be protected and mining activities should be environmentally friendly. The level of the Jong River should be monitored in seasons to determine the safe rate to redraw water in order to maintain the water balance.

\section{Acknowledgements:-}

The authors are grateful to Geohydroprobe Resources of Ghana who financed the fieldwork.

\section{References:-}

1. Anon. (1988), "The study on Watershed Degradation in Sierra Leone": www.iwmi.cgiar.org. Accessed: October $12,2013$.

2. Anon. (1999), "Water Quality Monitoring": A Practical Guide to the Design and Implementation of Freshwater Quality Studies and Monitoring Programmes, E and FN Spon, London, UK.

3. Anon. (2004), "Guidelines for Drinking-Water Quality": Training Pack. WHO, Geneva, Switzerland. WHO and UNICEF, 2003. Global Strategy for Infant and Young Child Feeding. World Health Organization, Geneva.

4. Anon. (2007), Final Report. National Aid Co-ordinating Secretariat. Consulting Group (ESCG), Freetown. pp. 1 $-47,189-196$.

5. Anon. (2012), "Sierra Leone Population”: www.tradingeconomics.com .Accessed: March 13, 2014.

6. Anon. (2014), "Feasibility Study for Manual Drilling Mapping of Favourable zones: Ministry for Water Resources and Energy. pp. 14.

7. Daveau, B. (1871), "Loma mountains in the Guinea dorsal",Massive mountains .IFAN.85: 11-33.

8. Foster, S. S. D. and Chilton, P. J. (2003), Groundwater the process and global significance of aquifer degradation. Phil. Trans. R. Soc.

9. Gadgil, A. (1998), Drinking water in developing countries, Ann. Rev. Energy Environ. 23, 253-286.

10. Harrelson, C. C., Raulins, C. L. and Potyondy, J. P. (1994), Stream channel references sites www.stream.fs.fed.US/publications/DDF/RM245E. Accessed:November 12, 2013.

11. Henry, R.W. and Thornley, P. (1979), Some geothermal aspect of polymetallic massive sulphide formation. Econ, Geol, 74, 1600-1612.

12. Johnson, R. G.and Johnson, J.A. (1991), State of Mangrove Resources and Coastal Environment in Sierra Leone. Paper presented at National Seminar in Fishery Industries Development, 25-29 November, Freetown.

13. Kesse, G.O. (1985), Mineral and Rock Resources of Ghana, A. A. Balkema, Rotterdam, 610 pp.

14. Kuma, J.S. (2010) "Unpublished MSc Lecture notes "Applied Hydrogeology." University of Mines and Technology, pp 172.

15. Levert, S. (2006), "Cultures of the world: Sierra Leone". Marshall Cavendish (Published 2007). pp. 8-9.

16. Morel, S. W. (2006), "The Geology and Mineral Resources of Sierra Leone: American Geological Institute. Economic Geology. 1979 V. 79 No. 7 p 1563-1576.

17. Murdoch, T. and Cheo, M. (1996), Stream foundation. Field guide watershed inventory and stream monitoring methods, Event, WA, 74 p.

18. Okun, F.G. (1994), Elements of water supply and wastewater disposal, Wiley Joppan- Second Edition. Pp 7080.

19. Sengupa, M. (1992), "Environmental Impacts of Mining, Monitoring, Restoration and Control", Lewis Publishers, New York, pp. 121-137.

20. Wright, R. (1982), Seasonal variations in water quality of West African river (R. Jong in Sierra Leone). Rev. Hydrobiol. Trop. 15(3): 193-199. 